\title{
Mould Filling Ability Characterisation of Cast Aluminium Alloys Using Design of Experiments
}

\author{
Samavedam Santhi, ${ }^{1}$ S. B. Sakri, ${ }^{2}$ \\ Dharwada Hanumantha Rao, ${ }^{3}$ and Srinivasan Sundarrajan ${ }^{4}$ \\ ${ }^{1}$ Department of Metallurgical and Materials Engineering, MGIT, Hyderabad 500075, India \\ ${ }^{2}$ Special Fabrication Division, DRDL, Hyderabad 500058, India \\ ${ }^{3}$ Mechanical Engineering Department, M.V.S.R. Engineering College, Hyderabad 501510, India \\ ${ }^{4}$ National Institute of Technology, Trichy 620015, India \\ Correspondence should be addressed to Samavedam Santhi, santhi_samave@yahoo.com \\ Received 23 February 2012; Revised 1 August 2012; Accepted 21 August 2012 \\ Academic Editor: Brij Kumar Dhindaw
}

Copyright ( $) 2012$ Samavedam Santhi et al. This is an open access article distributed under the Creative Commons Attribution License, which permits unrestricted use, distribution, and reproduction in any medium, provided the original work is properly cited.

Mould filling ability characteristic has been influencing the liquid metal flow, heat transfer, and solidification there by affecting the quality of aerospace castings. Mould filling is a critical parameter in the production of sound and quality castings, especially in the case of complex-shaped castings where section thickness is varying considerably. The mould filling ability of aluminium alloys LM6 and LM25 has been studied in the present investigation. Experimentation has been carried out using orthogonal array experimental layout. The process parameters studied in the present investigation are alloy composition, sand fineness, mould coating, and pouring temperature. The mould filling ability of selected aluminium alloy has been studied using pin test piece with cylindrical cores. The results from experimentation are analyzed to find the influence of the process parameters on mould filling ability. Based on the above, LM6 alloy has been found to have better mould filling ability characteristics and the analysis of variance has also revealed the same optimum factor combination.

\section{Introduction}

Metal casting is unique among metal forming processes for a variety of reasons [1]. Aluminum castings have played an integral role in the growth of the aluminum industry since its inception in the late 19th century. Popular aluminum casting alloys contain, in addition to strengthening elements, sufficient amounts of eutectic-forming elements (usually silicon) in order to have adequate fluidity to make the metal flow through the cavities. The aluminum castings and applications rapidly expanded to address the requirements of a wide range of engineering specifications and continuing market requirement to reduce vehicle weight and to increase fuel efficiency. Complicated physics involved in the casting process is fluid mechanics with phase change, shrinkage, porosity, macrosegregation in alloys, heat transfer between metal and mould, and thermal stress in the solidifying ingot [2]. Thin-wall aluminium alloy casting techniques can be used to produce clean castings of lower weight and with superior mechanical and physical properties compared to those produced by more complex traditional methods and are ideal for automotive applications [3]. The filling of the mould is an essential part of the entire casting cycle. Mouldfilling ability is the bottleneck of manufacturing thin-walled castings [4].

The solidification of the melt during the mould filling continuously changes the properties of liquid and solid phases. The filling conditions play a significant role on the casting quality. A good mould-filling metal has the ability to fill out the mould pattern and reproduce fine details of the mould $[5,6]$. Many defects in a casting generally originate at the filling stage [6].

The gating design is driven by the ideal mould filling time, which depends on the cast metal, casting weight, and minimum wall thickness [7]. Fast filling leads to turbulencerelated defects (such as mould erosion, air aspiration, and 
TABle 1: Chemical composition (\% wt).

\begin{tabular}{lccccccccccccc}
\hline Alloy & $\mathrm{Si}$ & $\mathrm{Fe}$ & $\mathrm{Cu}$ & $\mathrm{Mn}$ & $\mathrm{Mg}$ & $\mathrm{Ni}$ & $\mathrm{Zn}$ & $\mathrm{Pb}$ & $\mathrm{Sn}$ & $\mathrm{Ti}$ & Each & Total & $\mathrm{Al}$ \\
\hline LM6 & $10.5-13.5$ & 0.65 & 0.15 & 0.55 & 0.1 & 0.1 & 0.15 & 0.1 & - & 0.2 & 0.05 & 0.15 & Rem \\
LM25 & $6.5-7.5$ & 0.55 & 0.2 & 0.35 & $0.2-0.65$ & 0.15 & 0.15 & 0.15 & 0.05 & $0.05-0.25$ & 0.05 & 0.15 & Rem \\
\hline
\end{tabular}

inclusions). On the other hand, slow filling may cause defects related to premature solidification (such as cold shuts and misruns).

The integrity of a casting will be degraded substantially if high levels of free surface turbulence are experienced by the liquid metal during mould filling $[8,9]$. This is due to the entrapment and breakup of surface oxide film formed on the surface of liquid metal. This oxide film becomes trapped in the casting and behaves like a crack. This generally appears when large flat castings filled horizontally [10].

Mould filling is strongly dependent on the surface tension and viscosity of the metal. It is affected by the mould characteristic, melt composition, and melt cleanliness. The mould filling process that closely related to molten metal flow, heat transfer, and mass transfer process is a flow process at changeable temperature accompanied with heat loss and solidification [4]. Factors affecting mould filling generally are alloy composition, mould, sand fineness, wall thickness, mould coat [7], gating system $[7,11]$, pouring issue (pouring temperature), and filters [12].

Taguchi's methods belong to the class of approaches that attempt to ensure quality through design. The design of experiments using Taguchi's approach can economically satisfy the needs of problem solving and product/process design optimization projects in the manufacturing industry. Multiple process variables can be studied at the same time with Taguchi's orthogonal array-efficient designs, instead of in a hit-and-miss approach, providing very reproducible results. Due to the statistical balance of the designs, more potential combinations of process variables (at different levels) can be evaluated for the best overall combination, in small number of experiments.

Orthogonal array technique allowed many factors to be analysed with limited number of experiments. Orthogonal array of design of experiments makes the design to be balanced so that factor levels are weighted equally [5]. Because of this, each factor can be evaluated independently of all the other factors, so the effect of one factor does not influence the estimation of another factor. MINITAB software is used for experimental design $[13,14]$. Orthogonal arrays provide a set of well-balanced (minimum) experiments.

\section{Experimental Plan}

Designing of experiments is an efficient approach for improving a process. Changing more than one factor at a time to quickly obtain meaningful results and draw conclusions about how factors interact is the primary objective of the design of experiments. A full scale of experimentation requires 16 experiments which have been reduced to $8 \mathrm{ex}-$ periments using orthogonal array design of experiments.
TABLE 2: Factors and their levels.

\begin{tabular}{lcccc}
\hline & $\begin{array}{c}\text { Factor 1 } \\
\text { Alloy }\end{array}$ & $\begin{array}{c}\text { Factor 2 } \\
\text { Sand } \\
\text { fineness } \\
\text { (AFS No.) }\end{array}$ & $\begin{array}{c}\text { Factor 3 } \\
\text { Mould coat }\end{array}$ & $\begin{array}{c}\text { Factor 4 } \\
\text { Pouring } \\
\text { temperature }\left({ }^{\circ} \mathrm{C}\right)\end{array}$ \\
\hline Level 1 & LM25 & 25 & Graphite & $T$ \\
Level 2 & LM6 & 40 & No coating & $T+20^{\circ} \mathrm{C}$ \\
\hline
\end{tabular}

TABLE 3: L8 Orthogonal array.

\begin{tabular}{lcccc}
\hline $\begin{array}{l}\text { Exp. run } \\
\text { order }\end{array}$ & Alloy & $\begin{array}{c}\text { Sand fineness } \\
\text { (AFS no.) }\end{array}$ & Mould coat & $\begin{array}{c}\text { Pouring } \\
\text { temperature }\left({ }^{\circ} \mathrm{C}\right)\end{array}$ \\
\hline 1 & LM25 & 25 & $\begin{array}{c}\text { Graphite } \\
\text { (GC) }\end{array}$ & $T$ \\
2 & LM25 & 25 & $\begin{array}{c}\text { No coating } \\
\text { (NC) } \\
\text { Graphite } \\
\text { (GC) }\end{array}$ & $T+20$ \\
4 & LM25 & 40 & $\begin{array}{c}\text { No coating } \\
\text { (NC) }\end{array}$ & $T+20$ \\
5 & LM25 & 40 & $\begin{array}{c}\text { No coating } \\
\text { (NC) }\end{array}$ & $T$ \\
6 & LM6 & 25 & $\begin{array}{c}\text { Graphite } \\
\text { (GC) }\end{array}$ & $T+20$ \\
7 & LM6 & 25 & $\begin{array}{c}\text { Graphite } \\
\text { (GC) }\end{array}$ & $T+20$ \\
8 & LM6 & 40 & $\begin{array}{c}\text { No coating } \\
\text { (NC) }\end{array}$ & $T$ \\
\hline
\end{tabular}

For studying mould filling ability, the influencing parameters selected are alloy composition, sand fineness, mould coat, and pouring temperature.

Alloy composition affects the fluidity, filling characteristics, mechanical properties, and structure of the cast product. To study the influence of alloy composition, two alloys are taken for the present study; these are LM6 and LM25. Table 1 gives the chemical composition of the two alloys.

Another processing parameter is fineness of the sand which shows significant difference in the casting characteristics like surface finish and strength. AFS sand fineness numbers 25 and 40 are considered.

The third processing parameter is mould coat [5]. Generally mould coat provides smooth surface. Pouring temperature [12] influences fluidity, porosity, strength, and structure of the casting. Hence, pouring temperature with $20^{\circ} \mathrm{C}$ of super heat is considered as one of the process parameters for the present study.

Table 2 shows the details of the factors and their levels for the present study. Orthogonal array L8 $\left(2^{* *} 4\right)$ is used with four factors and 2 levels (for 8 runs) for experimental investigation as shown in Table 3. 

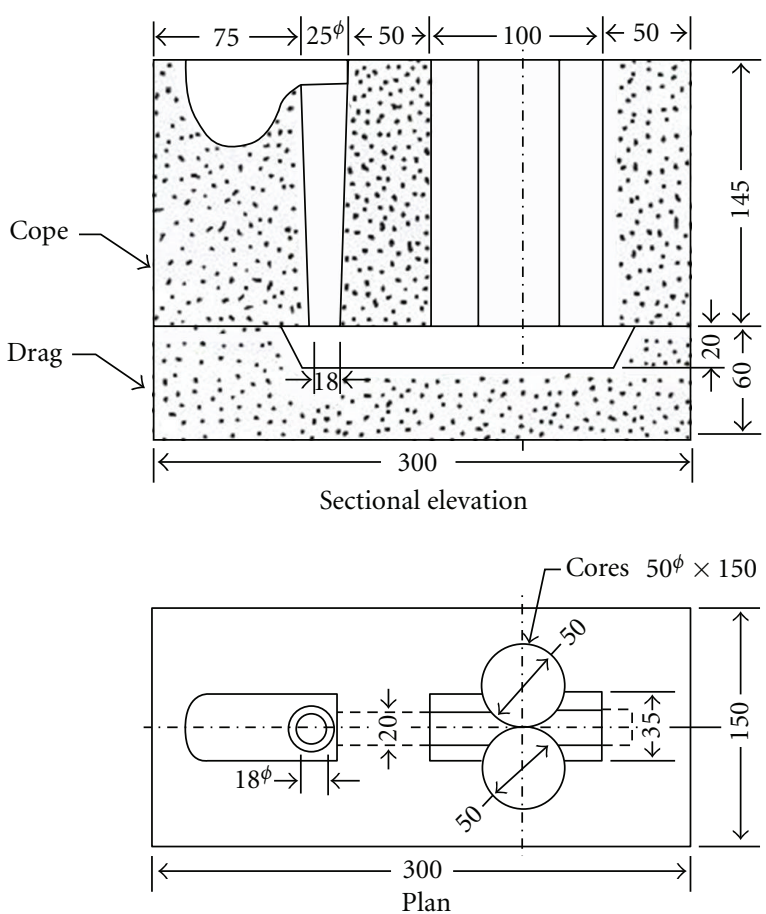

FIGURE 1: Schematic diagram of mould used for experimentation.

\section{Experimental Details}

The mould filling ability of these alloys has been studied using pin test piece with cylindrical cores designed by Engler and Ellerbrok as shown in Figure $1.50 \mathrm{~mm}$ diameter cylindrical cores are considered for the present study. The test casting consists of two fins of metal at both sides. The inverse of the diameter of curvature of the edge tip of the fin gives the value of the mould filling ability. The mould filling ability pin test piece is based on the determination of the diameter of meniscus of liquid metal just at the time of solidification in the test casting. It is possible to quantitatively determine the values of mould filling ability at various pressure heads using the pin test piece. The mould filling ability as the percentage length of the spiral which has successfully reproduced the contour to the total length gives only empirical values.

3.1. Preparation of Green Sand Mould. Testing arrangement for the mould filling ability is shown in Figure 2. Tooling for experiments and assembled mould for this experiment are given in Figure 2. The mould filling pattern and cylindrical cores are provided in the cope box and it is shown in Figure 2(a). The cope box, drag, and cylindrical cores are given in Figure 2(b). Top view of the assembled mould for mould filling ability experiments is shown in Figure 2(c).

The moulds are provided with dowel pins for perfect matching of cope and drag. Moulds are prepared with slight ramming. The patterns have been stripped after 3 hours.

Moulds are prepared using green sand process. The composition consists of Bentonite 5-6\% of sand weight and water is $5-8 \%$ of sand weight. In case of mould coatings the graphite paint is sprayed on to the mould and mould is dried immediately by lightening a flame on the painted surface.
3.2. Alloys. Alloys used in the present investigation are LM6 (Al-12Si) and LM25 (Al-7Si-0.4 Mg). Each alloy melting done with their respective same batch (belong to same heat) for all the 8 castings.

3.3. Melting and Pouring. The alloys are melted in an electric resistance furnace of capacity $20 \mathrm{Kg}$ provided with mild steel crucible. Temperature is measured with the help of a thermocouple. The furnace is put off and the crucible is lifted and put in a tilting device. The metal is tapped into a smaller crucible for pouring into the mould.

3.4. Process Variables Studied. The variables studied are alloy composition, sand fineness, mould coat, and pouring temperature.

\section{Analysis of Results}

Metal filling is an important phase of the casting process. The ability to fill and the contours play a significant role in reproducing the intricate details of the casting. The mould filling ability depends on the metallostatic balance between the metal pressure head and the surface tension of the mould. $H$ is the height of liquid metal column above the filling point. A higher metallostatic pressure gives higher velocity of molten metal and thereby higher fluidity. The casting fluidity and filling are driven by metallostatic pressure head.

The test casting obtained for experimental run order 7 is shown in Figure 3.

Using this test piece the mould filling ability value can be determined at various pressure heads ( $\mathrm{Hs}$ ) as shown in Figure 3. Pressure head is the height of liquid metal column above the filling point. The casting consists of two fins of metal at both sides.

The hot metal poured into the sprue fills the curved cavity between the two cylindrical cores having a line contact at the center. But it solidifies before it fills up the complete casting. The inverse of the diameter of curvature of the edge tip of the fin gives the value of the mould filling ability. The diameter at the tip of the fin gives the meniscus diameter of the liquid metal at the time of solidification as represented in Figure 4 for one particular pressure head.

It is difficult to measure the diameter of the tip of the edge and hence an indirect way of calculation has been used. As per Figure 5,

$$
R^{2}+(r+x)^{2}=(r+R)^{2},
$$

where $R=$ radius of the sand core, $\mathrm{mm}$,

$$
\begin{gathered}
R=25 \mathrm{~mm} \text { (radius of cylindrical core). } \\
r=\text { radius of the meniscus }(2 r=d), \mathrm{mm}, \\
2 x=\text { distance between edges, } \mathrm{mm},
\end{gathered}
$$

$$
\text { so } \frac{1}{d}=\frac{(R-x)}{\mathrm{x}^{2}}
$$

$$
\frac{1}{d}=\text { mould filling ability, } \frac{1}{\mathrm{~mm}},
$$




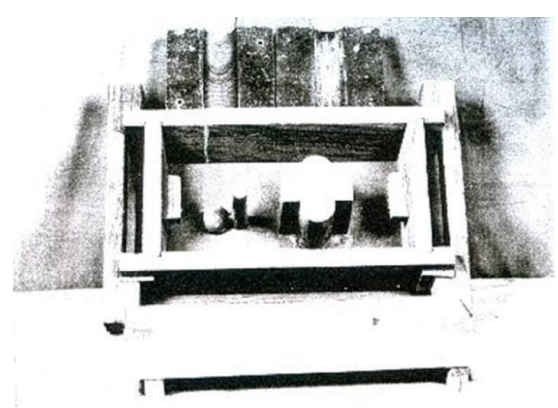

(a) Mould filling pattern and cylindrical cores

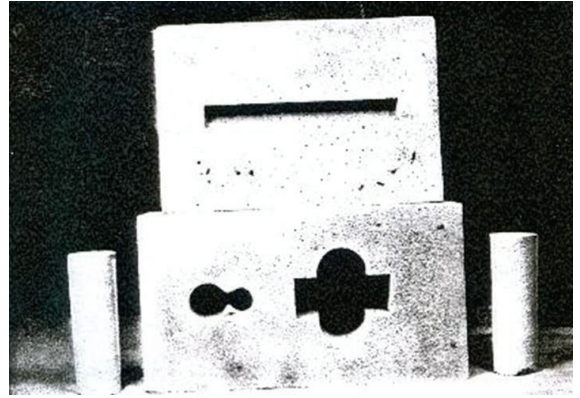

(b) Cope box, drag, and cylindrical cores

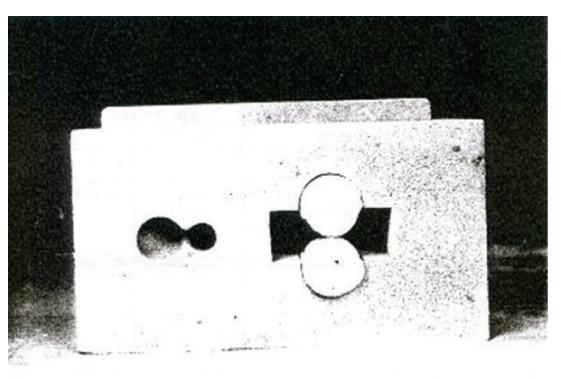

(c) Assembled mould for mould filling ability

FIGURE 2: Tooling for mould filling experiments and assembled mould for this experiment.

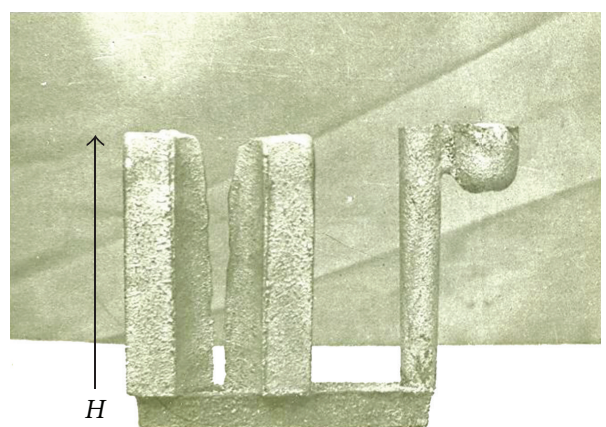

(a)

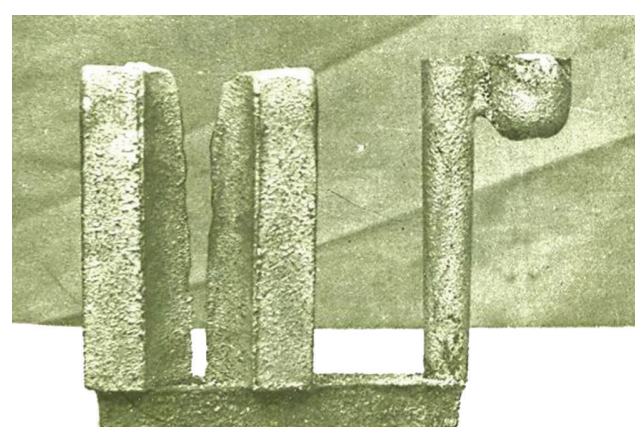

(b)

FIGURE 3: Mould filling ability test casting.

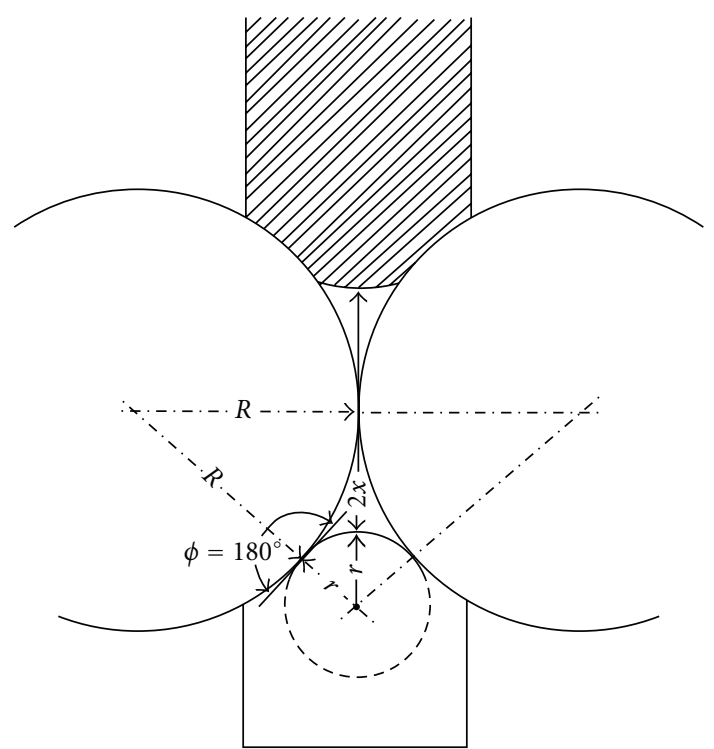

FIGURE 4: Measurement of mould filling ability.

Height gauge has been used to mark the height at every interval of $5 \mathrm{~mm}$ for each solidified casting. The distance between the fin edges, $2 x$, is measured with vernier micrometer for each $5 \mathrm{~mm}$ interval. The $2 x$ values for 8 experiments are given

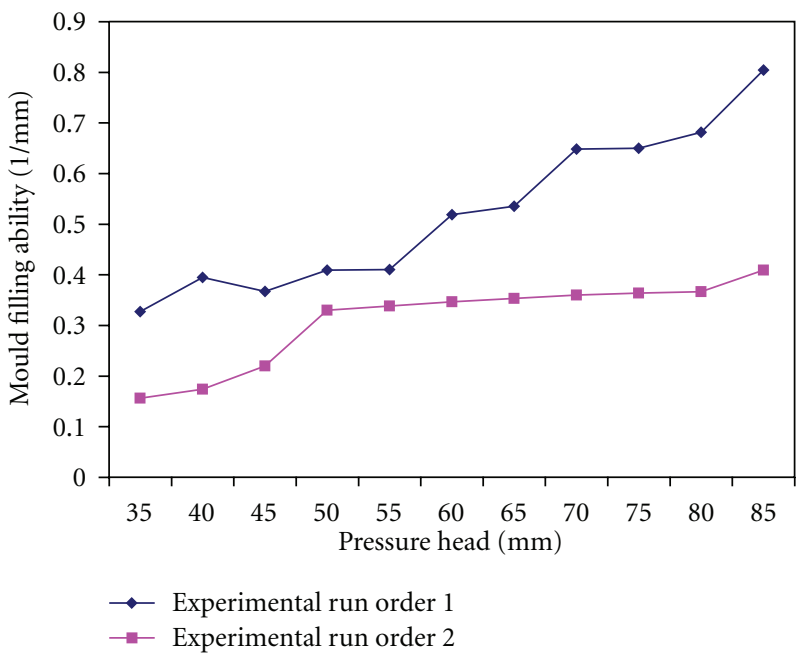

FIGURE 5: Influence of pressure head on mould filling ability.

at Table 4. The $x$ values are substituted in (1) and the mould filling ability calculated for all the 8 experiments. The mouldfilling ability values have been calculated for every $5 \mathrm{~mm}$ increment by using (1).

The mould filling ability values at various pressure heads for experimental run order 8 are given in Table 5 . The mould 
TABLE 4: The distance between the fin edges, $2 x$ in $\mathrm{mm}$.

\begin{tabular}{|c|c|c|c|c|c|c|c|c|}
\hline$H, \mathrm{~mm}$ & $\begin{array}{l}\text { Exp. run } \\
\text { order } 1\end{array}$ & $\begin{array}{l}\text { Exp. run } \\
\text { order } 2\end{array}$ & $\begin{array}{c}\text { Exp run } \\
\text { order } 3\end{array}$ & $\begin{array}{c}\text { Exp run } \\
\text { order } 4\end{array}$ & $\begin{array}{c}\text { Exp run } \\
\text { order } 5\end{array}$ & $\begin{array}{l}\text { Exp run } \\
\text { order } 6\end{array}$ & $\begin{array}{c}\text { Exp run } \\
\text { order } 7\end{array}$ & $\begin{array}{c}\text { Exp run } \\
\text { order } 8\end{array}$ \\
\hline 35 & 5.4 & & 7 & & 9.6 & 9.759 & 10.6 & 7.5 \\
\hline 40 & 5.9 & 3.8 & 7.3 & 3.5 & 9.8 & 9.79 & 11 & 8 \\
\hline 45 & 5.7 & 4 & 7.4 & 4.5 & 10 & 9.988 & 11.1 & 8.1 \\
\hline 50 & 6 & 4.5 & 7.5 & 4.6 & 10.1 & 10.252 & 11.2 & 8.2 \\
\hline 55 & 6 & 5.5 & 7.8 & 5 & 10.2 & 10.35 & 11.8 & 8.3 \\
\hline 60 & 6.7 & 5.5 & 7.9 & 5.5 & 10.5 & 10.45 & 12 & 8.5 \\
\hline 65 & 6.8 & 5.55 & 8 & 6 & 10.55 & 10.65 & 12.5 & 8.5 \\
\hline 70 & 7.6 & 5.6 & 8.5 & 6.5 & 10.6 & 10.75 & 13 & 8.5 \\
\hline 75 & 7.3 & 5.65 & 8.5 & 6.8 & 10.7 & 10.85 & 13.5 & 8.6 \\
\hline 80 & 7.6 & 5.68 & 9 & 6.9 & 10.9 & 10.98 & 13.6 & 8.7 \\
\hline 85 & 8.2 & 5.7 & 10 & 7 & 11 & 11.5 & 14 & 9 \\
\hline 90 & 7.3 & 6 & 11 & 7.1 & & 11.55 & 14.1 & 10 \\
\hline
\end{tabular}

TABLE 5: Mould filling ability calculations.

\begin{tabular}{lccc}
\hline S. no. & $H, \mathrm{~mm}$ & $2 x, \mathrm{~mm}$ & $1 / d \mathrm{~mm}^{-1},\left[(R-x) / x^{2}\right]$ \\
\hline 1 & 0 & 5 & 0.278 \\
2 & 5 & 5.5 & 0.34 \\
3 & 10 & 6 & 0.408 \\
4 & 15 & 6.2 & 0.438 \\
5 & 20 & 6.5 & 0.485 \\
6 & 25 & 6.8 & 0.536 \\
7 & 30 & 7 & 0.569 \\
8 & 35 & 7.5 & 0.662 \\
9 & 40 & 8 & 0.762 \\
10 & 45 & 8.1 & 0.783 \\
11 & 50 & 8.2 & 0.806 \\
12 & 55 & 8.3 & 0.826 \\
13 & 60 & 8.5 & 0.871 \\
14 & 65 & 8.5 & 0.871 \\
15 & 70 & 8.5 & 0.871 \\
16 & 75 & 8.6 & 0.892 \\
17 & 80 & 8.7 & 0.9165 \\
18 & 85 & 9 & 0.99 \\
19 & 90 & 10 & 1.25 \\
\hline
\end{tabular}

filling ability for 8 experimental run orders has been given in Table 6 .

4.1. Influence of Pressure Head on Mould Filling Ability of Aluminium Alloys. The mould filling ability is expressed as the reciprocal of the diameter of the meniscus of fin edge in the solidified test casting. It is expressed as a curve showing its variation with respect to pressure head $(H)$ as measured on the test casting. So in present study the mould filling ability can be expressed as a curve showing its variation with pressure head. The mould filling ability values have been calculated for every $5 \mathrm{~mm}$ increment by using (1). The mould filling ability values at various pressure heads for experimental run orders 1 to 4 are calculated and plotted
(Figure 5) showing that effect of pressure head on mould filling ability of LM25. This indicates that the mould filling ability increases with increase in pressure head.

The mould filling ability expressed as reciprocal of the diameter of the meniscus of fin edge in the solidified test casting. The mould filling ability is also plotted as a curve showing its variation with pressure head. Pressure head plays a very important role in the mould filling ability of metals. Experiments have been conducted to calculate mould filling ability of Aluminium alloys (LM6 and LM25). The mould filling ability increases with increase in pressure head. A higher-pressure head gives higher velocity of molten metal and better filling. Increase in pressure head leads to increase in the metallostatic force, allowing the liquid to enter the finer contours between the cylindrical cores thereby reducing the fin edge and increasing the mould filling ability values.

If the moulds were at the same temperature as of the molten metal during pouring, the mould filling ability follows the equation given below:

$$
\begin{gathered}
\frac{1}{d}=\frac{h \cdot \rho \cdot g}{2 \sigma \cdot \cos \varphi}, \\
\frac{1}{d}=\text { mould filling ability, } 1 / \mathrm{mm}, \\
h=\text { pressure head, } \mathrm{mm}, \\
\rho=\text { density, gm } / \mathrm{cc}, \\
g=\text { acceleration due to gravity, } \mathrm{m} / \mathrm{sec}^{2}, \\
\sigma=\text { surface tension, dynes } / \mathrm{cm}, \\
\varphi=\text { angle of contact. }
\end{gathered}
$$

The factors which influence the mould filling ability in liquid region are surface tension and contact angle. The factors which influence the mould filling ability in solidifying region are cooling conditions. In the present studies the experiments have been conducted in solidifying region. So the mould filling ability depends on pressure head while the surface 
TABLE 6: The mould-filling ability for 8 experimental run orders.

\begin{tabular}{lcccccccc}
\hline$H, \mathrm{~mm}$ & $\begin{array}{c}\text { Exp. run } \\
\text { order 1 }\end{array}$ & $\begin{array}{c}\text { Exp. run } \\
\text { order 2 }\end{array}$ & $\begin{array}{c}\text { Exp. run } \\
\text { order 3 }\end{array}$ & $\begin{array}{c}\text { Exp. run } \\
\text { order } 4\end{array}$ & $\begin{array}{c}\text { Exp. run } \\
\text { order 5 }\end{array}$ & $\begin{array}{c}\text { Exp. run } \\
\text { order 6 }\end{array}$ & $\begin{array}{c}\text { Exp. run } \\
\text { order 7 }\end{array}$ & $\begin{array}{c}\text { Exp. } \\
\text { run order 8 }\end{array}$ \\
\hline 35 & 0.326906 & 0.14784 & 0.569767 & 0.124 & 1.14 & 1.1833 & 1.425888 & 0.6617 \\
40 & 0.394671 & 0.156277 & 0.624005 & 0.131 & 1.19 & 1.191794 & 1.551282 & 0.7619 \\
45 & 0.366704 & 0.17391 & 0.642723 & 0.22 & 0.125125 & 1.2466 & 1.583676 & 0.7829 \\
50 & 0.409091 & 0.22 & 0.661765 & 0.233 & 1.2783 & 1.322 & 1.616495 & 0.8043 \\
55 & 0.41 & 0.33 & 0.720853 & 0.2777 & 1.307 & 1.35 & 1.822513 & 0.826 \\
60 & 0.51836 & 0.338 & 0.741211 & 0.33988 & 1.39577 & 1.38 & 1.894737 \\
65 & 0.535185 & 0.3464 & 0.761905 & 0.409 & 1.41 & 1.44 & 2.083333 \\
70 & 0.648113 & 0.3531 & 0.870482 & 0.48565 & 1.42588 & 1.47 & 2.283784 & 0.86 \\
75 & 0.65 & 0.3598 & 0.881815 & 0.535 & 1.4566 & 1.503 & 2.496575 & 0.89 \\
80 & 0.681132 & 0.3639 & 0.987805 & 0.55 & 1.5193 & 1.544 & 2.540659 & 0.9136 \\
85 & 0.8043 & 0.3666 & 1.25 & 0.5697 & 1.5512 & 1.7175 & 2.722222 & 0.98 \\
90 & 0.826 & 0.4091 & 1.551282 & 0.587529 & 1.583676 & 1.735 & 2.768942 \\
\hline
\end{tabular}

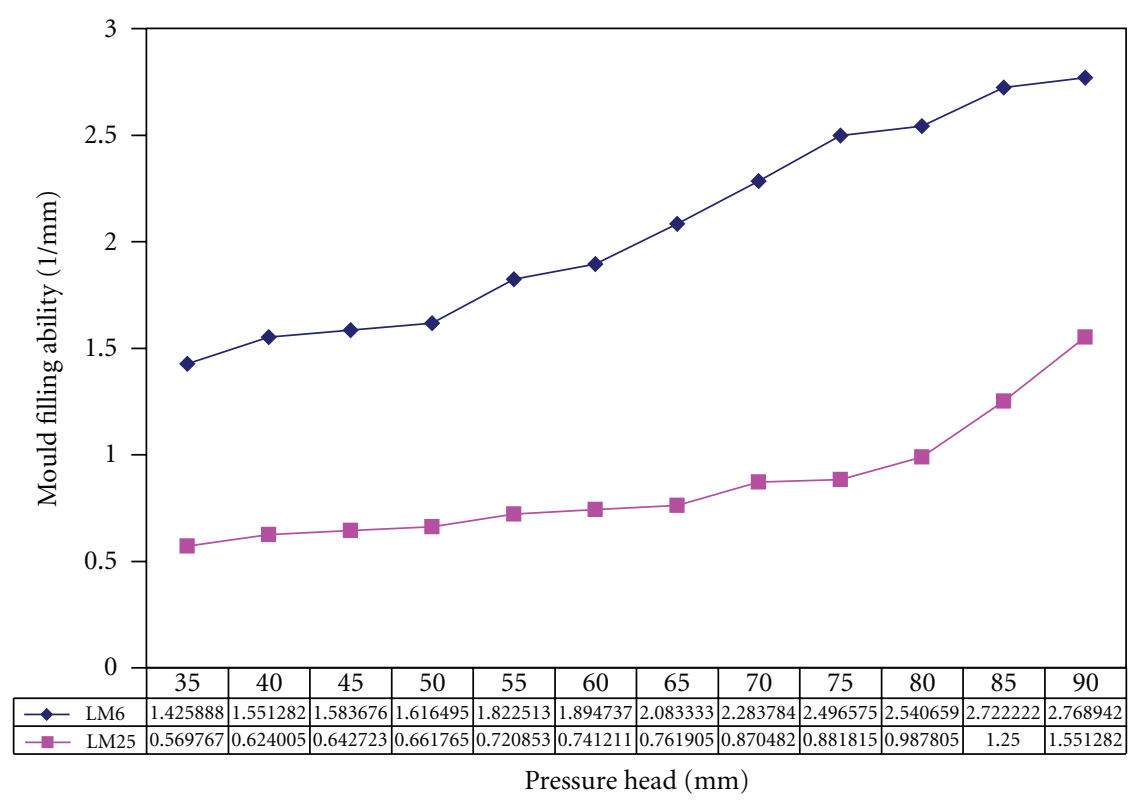

FIGURE 6: Influence of silicon on mould filling ability of LM6 and LM25.

tension and density are neglected and an angle of contact of $180^{\circ}$ is assumed. Higher pressure heads lead to higher mould filling ability because the metal has to be in contact with larger area in order to penetrate into cavity which promotes faster solidification.

4.2. Influence of Silicon Content on Mould Filling Ability. The mould filling ability increases with increase in silicon content in the alloy. LM6 is the eutectic alloy and it contains more silicon content of 12 weight percentage. Higher the silicon content higher will be the fluidity. Silicon additions improve casting characteristics by improving fluidity, feeding, and hot tear resistance.

This has been shown in Figure 6. LM6 having better mould filling ability than LM25 alloy attributes mainly to the higher silicon content in LM6 alloy. The mould filling ability values corresponding to Figure 6 have been calculated using (1). The mould filling ability values at various pressure heads for LM6 and LM25 are plotted.

4.3. Influence of Pouring Temperature on Mould Filling Ability. Pouring temperature affects the mould filling ability. Mould filling ability value increases with increase in pouring temperature. From the present experiments, it has been shown in Figure 7. Increase in pouring temperature increases the heat content of the alloy, resulting in alloy being liquid for longer duration. This promotes the metallostatic pressure head to act on the liquid metal for a longer period of time, thus forcing the metal to easily enter the fine contours.

4.4. Influence of Sand Fineness on Mould Filling Ability. Sand fineness plays a very important role in the moulding process. 


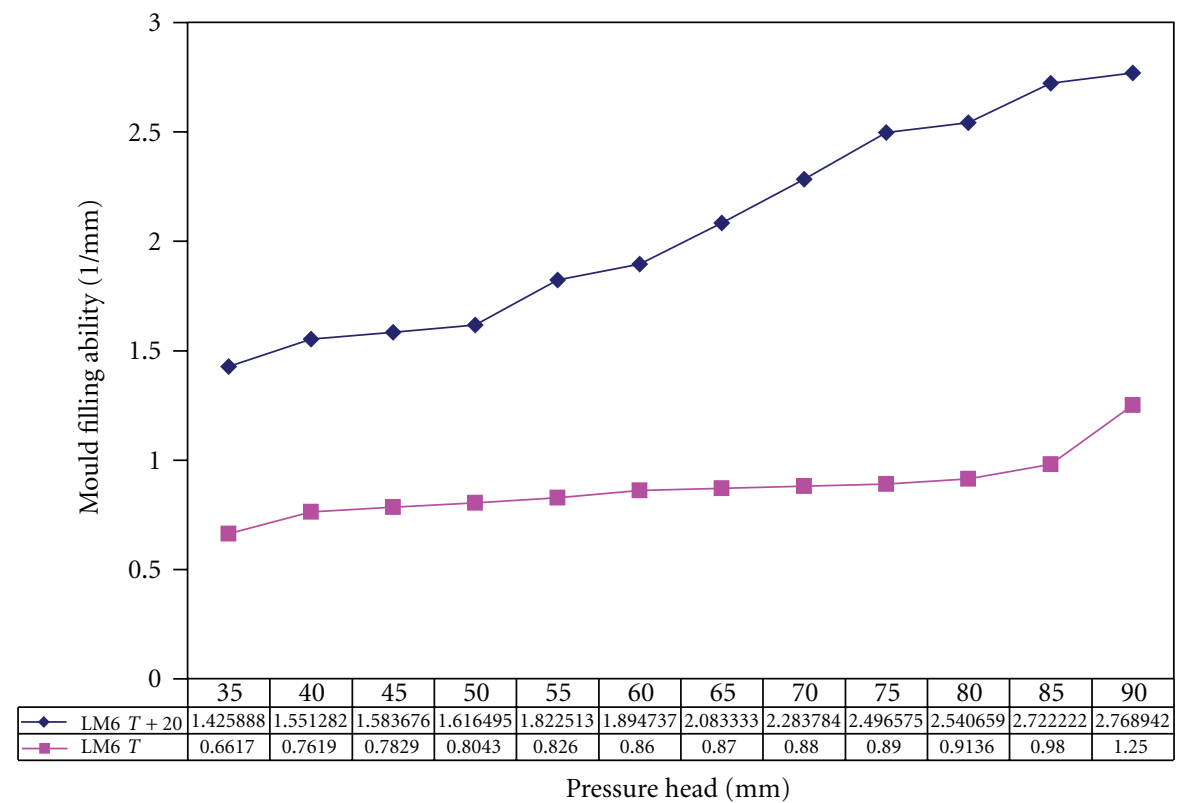

FIGURE 7: Influence of pouring temperature on mould filling ability of LM6.

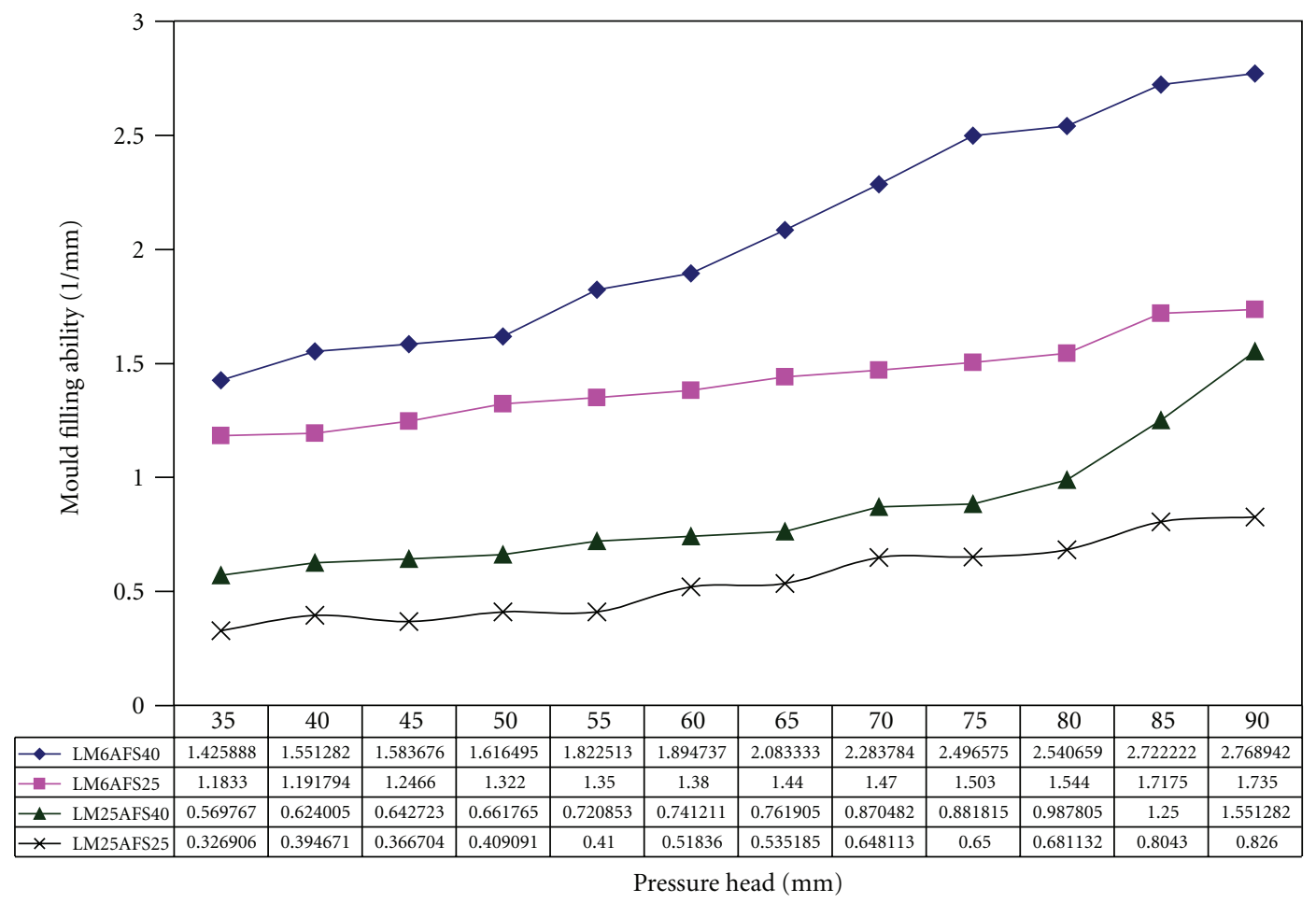

FIGURE 8: Influence of fineness of sand on mould filling ability of LM6 and LM25.

In the following experiments, the fineness of sand being used for cylindrical cores varies from fine sand and to coarse sand. Experimental results show that the mould filling ability increases with increase in sand fineness from Figure 8. The coarse sand is having more chilling power and solidifies the metal faster. This restricts the filling up of the cavity contours between the cylindrical sand cores and reduces the mould filling ability.

4.5. Influence of Mould Coating on Mould Filling Ability. Mould coating plays a significant role in the moulding process. Experiments have been conducted with graphite coating 


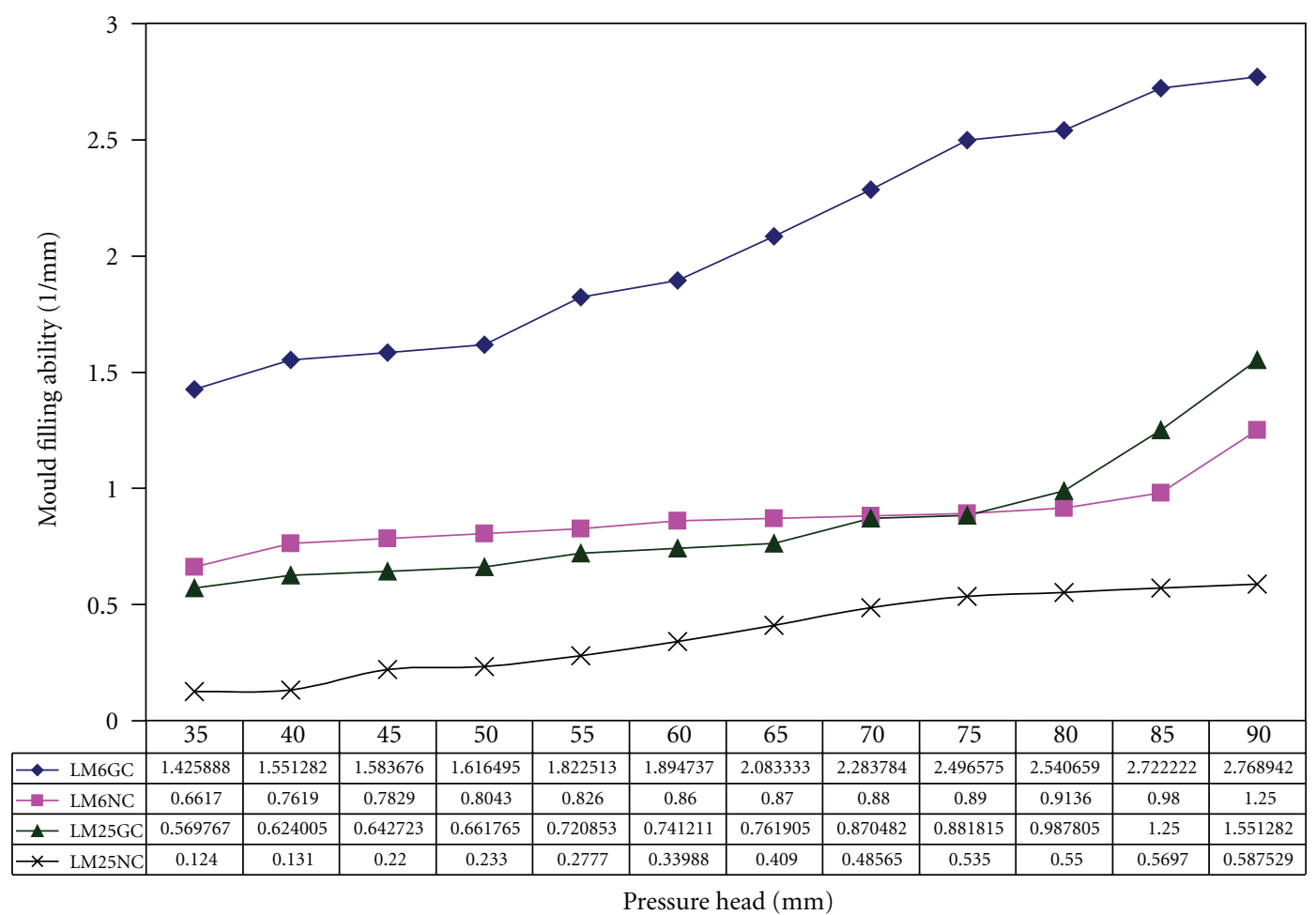

FIGURE 9: Influence of graphite coating on mould filling ability of LM6 and LM25.

TABLE 7: Response table.

\begin{tabular}{|c|c|c|c|c|c|}
\hline Exp. run order & Alloy & Sand fineness (AFS no.) & Mould coat & Pouring temperature $\left({ }^{\circ} \mathrm{C}\right)$ & $1 / \mathrm{d} \mathrm{mm}^{-1}$ \\
\hline 1 & LM25 & 25 & Graphite (GC) & $T$ & 0.624005 \\
\hline 2 & LM25 & 25 & No coating (NC) & $T+20$ & 0.40909 \\
\hline 3 & LM25 & 40 & Graphite (GC) & $T$ & 1.55 \\
\hline 4 & LM25 & 40 & No coating (NC) & $T+20$ & 0.58753 \\
\hline 5 & LM6 & 25 & No coating (NC) & $T$ & 1.55 \\
\hline 6 & LM6 & 25 & Graphite (GC) & $T+20$ & 1.73453 \\
\hline 7 & LM6 & 40 & Graphite (GC) & $T+20$ & 2.7689 \\
\hline 8 & LM6 & 40 & No coating (NC) & $T$ & 1.25 \\
\hline
\end{tabular}

on the mould. Mould coating improves the mould filling ability. This is by creating a smooth mould metal interface which provides less resistance to metal filling the contours. Results are shown in Figure 9.

4.6. Analysis of Variance (ANOVA). To study the characteristics of mould filling ability, it is necessary to study, all the process parameters together. In the present study Taguchi orthogonal array L8 $(2 * * 4)$ is used with four factors and 2 levels (for 8 runs) as indicated in Table 2 and response values are given in Table 7 . The interactions selected for this study are

(i) alloy and sand fineness (AFS no.),

(ii) alloy and mould coat,

(iii) alloy and pouring temperature.
ANOVA values for mould filling ability are calculated using MINITAB and it is given at Table 8 .

$P$ is used to determine whether a factor is significant, typically to compare against an alpha $(\alpha)$ value of 0.1 . Alpha is frequently referred to as the level of significance and is expressed as a probability ranging between 0 and 1 . If the $P$ value is lower than 0.1 , then the factor is significant. Choosing a larger value for $\alpha$ is better for aerospace applications. The analysis of variance indicates that the alloy factor is considered more significant in influencing mould filling ability. It is seen that the alloy content and pouring temperature interaction contribute more to mould filling ability value.

Use of main effects' plot in conjunction with an analysis of variance (ANOVA) is useful when there have been several factors. The effect is the mean for that level minus the overall 
TABLE 8: ANOVA.

\begin{tabular}{|c|c|c|c|c|c|}
\hline Source & Degrees of freedom & Sum of squares & Mean squares & Factor & $P$ \\
\hline Alloy & 1 & 2.13501 & 2.13501 & 8.33 & 0.045 \\
\hline AFS no. & 1 & 0.42265 & 0.42265 & 1.02 & 0.370 \\
\hline Pouring temperature & 1 & 0.03459 & 0.03459 & 0.14 & 0.732 \\
\hline Mould coat & 1 & 1.03739 & 1.03739 & 4.05 & 0.114 \\
\hline Alloy $*$ sand fineness & 1 & 0.01712 & 0.01712 & 0.04 & 0.849 \\
\hline Alloy $*$ mould coat & 1 & 0.03459 & 0.03459 & 0.14 & 0.732 \\
\hline Alloy $*$ pouring temperature & 1 & 1.03739 & 1.03739 & 4.05 & 0.114 \\
\hline Error & 4 & 1.02461 & 0.25615 & & \\
\hline Total & 11 & 5.74335 & & & \\
\hline
\end{tabular}
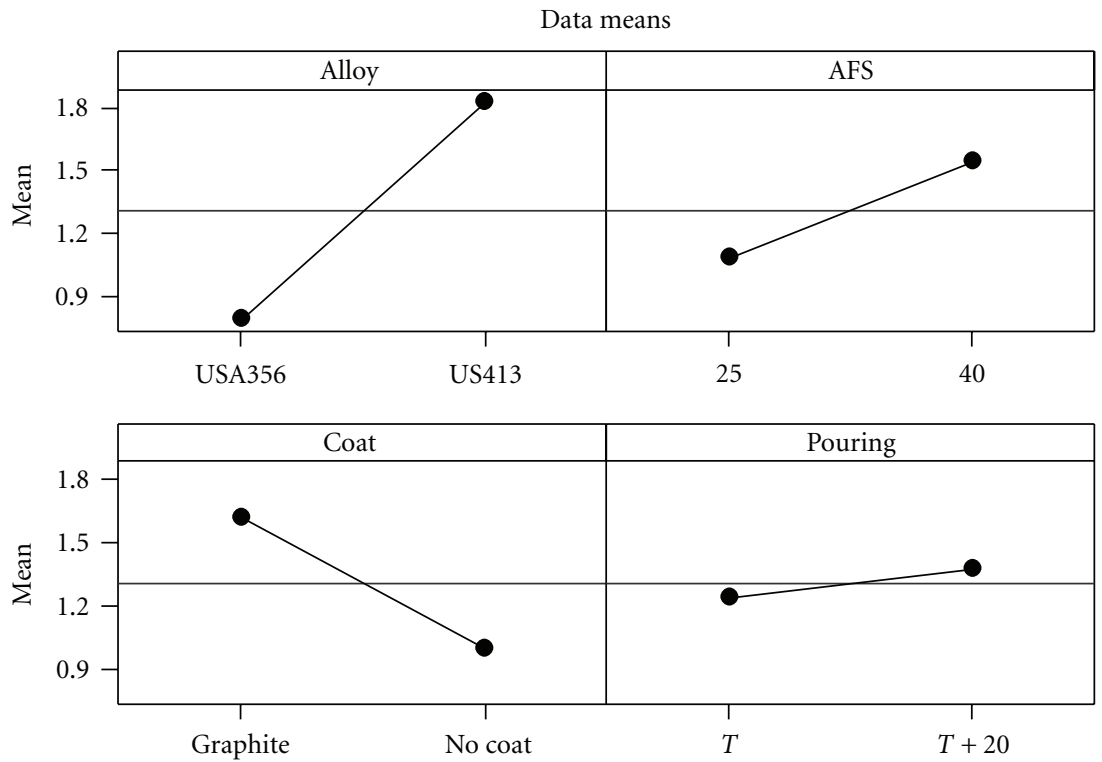

FIgURE 10: Main effects' plot for mould filling ability.

TABLE 9: The effects are summarized.

\begin{tabular}{lccc}
\hline Factor & Mean & \multicolumn{2}{c}{ Effect (mean - overall mean) } \\
\hline LM6 & 1.82586 & $1.82586-1.309$ & 0.51686 \\
LM25 & 0.79266 & $0.79266-1.309$ & -0.51634 \\
Pouring temp T & 1.24350 & $1.24350-1.309$ & -0.0655 \\
Pouring temp T+20 & 1.37501 & $1.37501-1.309$ & 0.06601 \\
GC & 1.66936 & $1.66936-1.309$ & 0.36036 \\
NC & 0.94915 & $0.94915-1.309$ & -0.35985 \\
25 & 1.07941 & $1.07941-1.309$ & -0.22959 \\
40 & 1.53911 & $1.53911-1.309$ & 0.23011 \\
\hline
\end{tabular}

mean for the factor. The effects are summarized at Table 9 . The overall mean is 1.309 for the present study from the ANVOA calculations.

Main effects' plot for mould filling ability values isshown in Figure 10. The magnitude of an effect is related to its distance from the mean. A reference line is drawn for the representing the overall mean. Lines are not horizontal (parallel to the $x$-axis), for all the four factors of the present study, so there is a main effect present. The main effects plot indicates that the alloy, mould coat, sand fineness, and pouring temperature are influencing the mould filling ability. In case of alloy factor, the difference in the vertical position of the plotted points is more, hence magnitude of the main effect is greater.

The main effects' plot indicates an optimum factor combination of LM6, graphite coat, sand fineness no. 40, and pouring temperature $T+20$ for getting better mould filling ability.

Correlation coefficient quantifies the strength of the linear association between two variables.

To ascertain the strength of association, correlation coefficient between the two alloys is calculated using the formula

$$
\text { Correlation }(r)=\left[\frac{(N \Sigma X Y-(\Sigma X)(\Sigma Y))}{\operatorname{Sqrt}\left(\left[N \Sigma X^{2}-(\Sigma X)^{2}\right]\left[N \Sigma Y^{2}-(\Sigma Y)^{2}\right]\right)}\right] \text {, }
$$


TABLE 10: Correlation coefficient for mould filling ability values.

\begin{tabular}{cccccc}
\hline$N$ & $X(\mathrm{LM} 6)$ & $Y(\mathrm{LM} 25)$ & $X \times Y$ & $X^{2}$ & $Y^{2}$ \\
\hline 1 & 1.55 & 0.624 & 0.967208 & 2.4025 & 0.389382 \\
2 & 1.7345 & 0.4091 & 0.709579 & 3.008594 & 0.167355 \\
3 & 2.7689 & 1.55 & 4.291795 & 7.666807 & 2.4025 \\
4 & 1.25 & 0.5875 & 0.734413 & 1.5625 & 0.345192 \\
\hline
\end{tabular}

where $N=$ number of values, $X=$ mould filling ability values for LM6, and $Y=$ mould filling ability values for LM 25.

The results of mould filling ability values used to find the correlation coefficient value are given in Table 10 .

The correlation coefficient always takes a value between -1 and 1 , with +1 indicating perfect correlation.

The correlation coefficient value obtained is 0.899242 indicating a strong, positive relationship.

\section{Conclusions}

The mould filling ability characteristics of LM6 and LM25 alloys have been studied using pin test piece with cylindrical cores. Mould filling ability increases with increase in metallostatic/pressure head. Silicon content in the alloys improves the mould filling ability. LM6 is having better mould filling ability than LM25. The mould filling ability increases with increase in fineness of sand because coarse sand is having more chilling power and solidifies the metal faster. Mould coat improves mould filling ability by providing less resistance to liquid metal flow. Alloy factor has been considered more significant in influencing mould filling ability. The main effects' plot has been indicating an optimum factor combination of LM6, graphite coat, sand fineness no. 40, and pouring temperature $T+20$ for getting better mould filling ability.

\section{Acknowledgments}

The authors extend their thanks to the Director, the Directorate of Engineering, and the Director DRDL for providing support and permission for carrying out this R\&D work.

\section{References}

[1] ASM Metals Handbook, Volume 15, Casting, ASM INTERNATIONAL, The Materials Information Company.

[2] S. V. Shepel and S. Paolucci, "Numerical simulation of filling and solidification of permanent mold castings," Applied Thermal Engineering, vol. 22, no. 2, pp. 229-248, 2002.

[3] Prepared by Energetics, Incorporated: Aluminum industry roadmap for the automotive market: Enabling Technologies and Challenges for Body Structures and Closures, The Aluminum Association, Inc., with support from the U.S. Department of Energy, 1999.

[4] Y. Su, T. Zhang, J. Guo et al., "Physical simulation of moldfilling processing of thin-walled castings under traveling magnetic field," Journal of Materials Science and Technology, vol. 20, no. 1, pp. 27-30, 2004.
[5] S. Sundarrajan and H. M. Roshan, "Studies on mould filling ability characteristics of Mg-Al Alloys," Transactions of the American Foundrymen's Society, pp. 607-616, 1989.

[6] R. W. Lewis, A. S. Usmani, and J. T. Cross, "Efficient mould filling simulation in castings by an explicit finite element method," International Journal for Numerical Methods in Fluids, vol. 20, no. 6, pp. 493-506, 1995.

[7] M. C. Flemings, Solidification Processing, Mcgraw-Hill, London, UK, 1974.

[8] N. R. Green and J. Campbell, "Influence in oxide film filling defects on the strength of Al-7si-Mg Alloy Castings," Transactions of the American Foundry Society, vol. 114, pp. 341-347, 1994.

[9] C. Reilly, N. R. Green, M. R. Jolly, and J. C. Gebelin, "Using the calculated froude number for quality assessment of casting filling methods," in Proceedings of the 12th International Conference on Modeling of Casting, Welding, and Advanced Solidification Processes, pp. 419-426, June 2009.

[10] M. Jolly, "Prof. John Campbell's ten rules for making reliable castings," JOM, vol. 57, no. 5, pp. 19-28, 2005.

[11] C. J. Cooksey, V. Kondic, and J. Wilcock, "The casting fluidity of some foundry alloys," The British Foundryman, vol. 52, p. 381, 1959.

[12] B. Sirrell and J. Campbell, "Mechanism of filtration in reduction of casting defects due to surface turbulence during mould filling," Transactions of the American Foundrymen's Society, vol. 105, pp. 645-654, 1998.

[13] User Manual of MINITAB.

[14] D. Hanumantha Rao, G. R. N. Tagore, and G. Rangajanardhan, "Process simulation of aluminium alloy casting solidification for controlled porosity and cooling rate," Indian Foundry Journal, vol. 52, no. 5, pp. 26-34, 2006. 

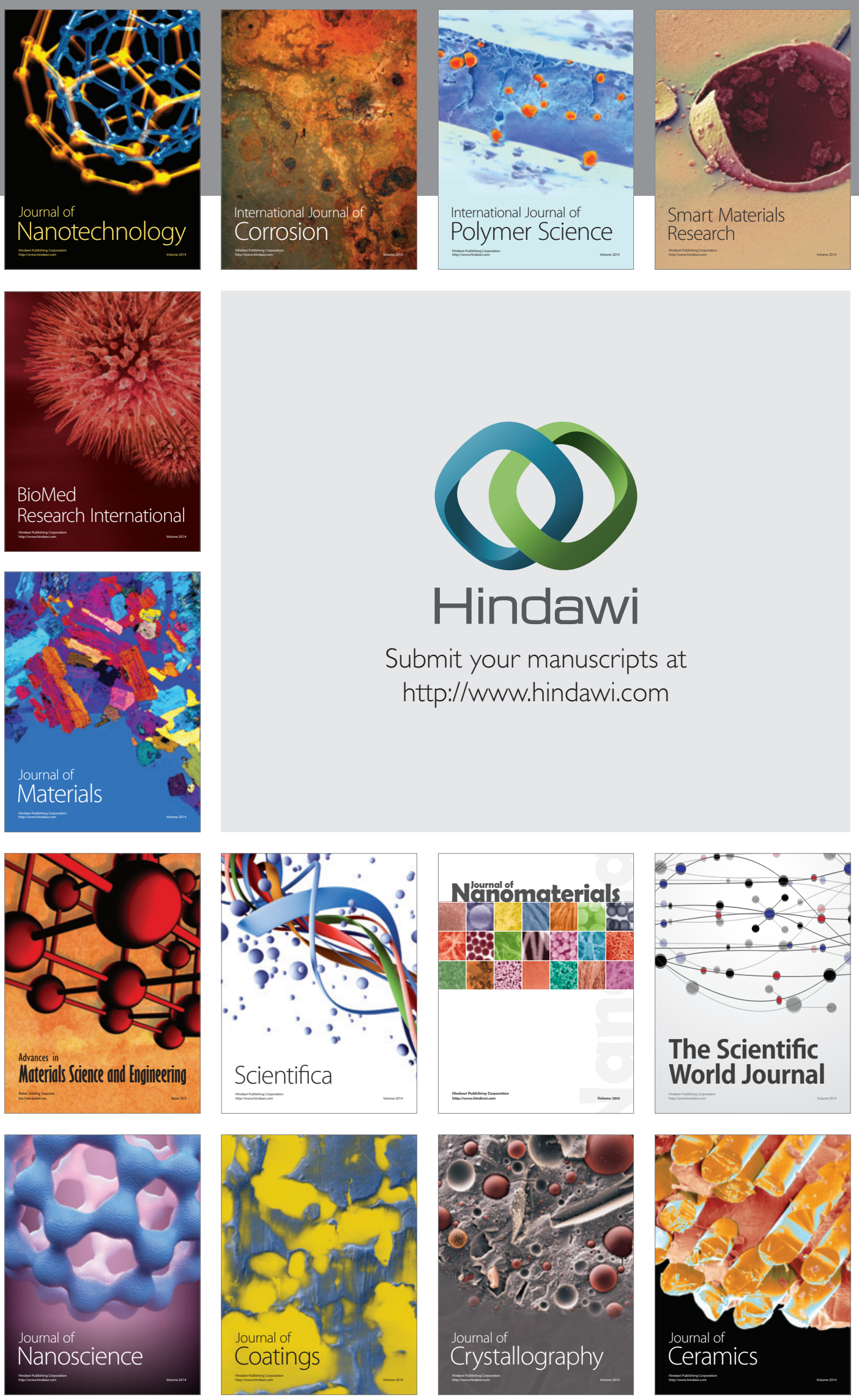

The Scientific World Journal

Submit your manuscripts at

http://www.hindawi.com

\section{World Journal}

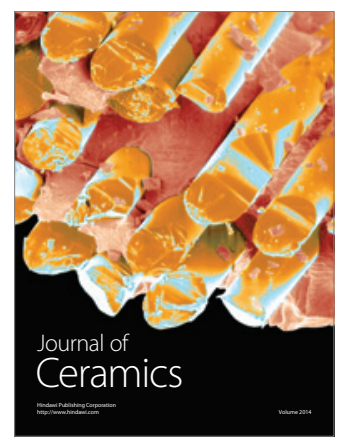

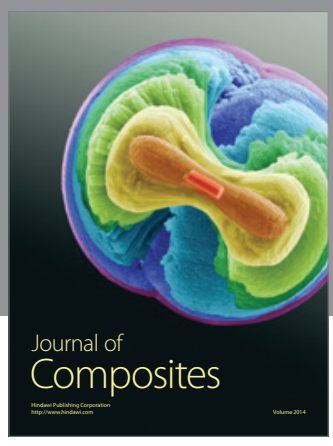
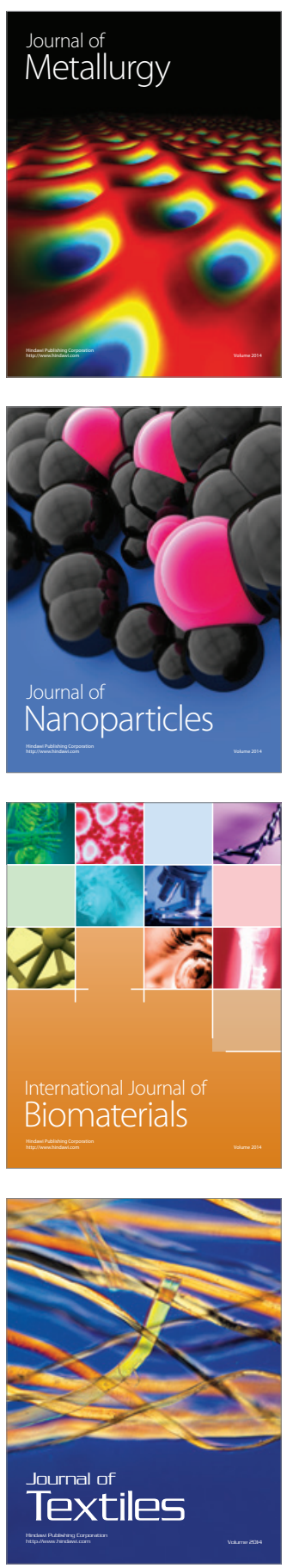